\title{
ГЕНДЕРНО-ВІКОВІ ТА ОРГАНІЗАЦІЙНО- ПРОФЕСІЙНІ ЧИННИКИ КРЕАТИВНОГО ПОТЕНЦІАЛУ ФАХІВЦІВ СОЦІАЛЬНОЇ РОБОТИ
}

Балахтар В. В., к. пед. наук, доц..

Украӥна, м. Чернівичі, кафедра педагогіки та соичіальної роботи Чернівецьького національного університету імені Юрія Федьковича

ORCID ID 0000-0001-6343-2888

DOI: https://doi.org/10.31435/rsglobal_ws/30082018/6079

\section{ARTICLE INFO}

Received: 16 July 2018

Accepted: 25 August 2018

Published: 30 August 2018

\section{KEYWORDS}

creativity,

creative potential,

gender characteristics,

Social Work specialist,

stages of professional development.

\begin{abstract}
The article deals with the age and organizational factors of the creative potential of Social Work specialists. On the basis of the results of the empirical study, the level of creative potential, the indicator of creative potential depending on gender, place of the residence of specialists, length of work, the stage of professional development ("selfdetermination as a specialist", "the stage of self-projecting of professional path"), "self-regulation in professional self-development, self-affirmation and self-improvement in professional activity ","selfrealization of a specialist as a professional, the achievement of "achme", "a reflection of professional experience and self-creation of meaning further way of life".
\end{abstract}

Citation: Балахтар В. В. (2018) Henderno Vikovi ta Orhanizatsiino Profesiini Chynnyky Kreatyvnoho Potentsialu Fakhivtsiv Sotsialnoi Roboty. World Science. 8(36), Vol.3. doi: 10.31435/rsglobal_ws/30082018/6079

Copyright: (C) 2018 Балахтар В. В. This is an open-access article distributed under the terms of the Creative Commons Attribution License (CC BY). The use, distribution or reproduction in other forums is permitted, provided the original author(s) or licensor are credited and that the original publication in this journal is cited, in accordance with accepted academic practice. No use, distribution or reproduction is permitted which does not comply with these terms.

Постановка проблеми. Креативний потенціал фахівців 3 соціальної роботи як професійної діяльності 3 надання допомоги та підтримки людей, які опинились в скрутній ситуації, є невід'ємною складовою і обов'язковою умовою їхнього розвитку, що забезпечує готовність до прийняття нетипових рішень, рішучості, впевненості, що з будь-якої ситуації $\epsilon$ вихід, а будь-яке завдання може мати декілька способів розв'язання, особливо в умовах, де використання сталих схем, стандартних розумових операцій не сприяє досягненню успіху. Необхідність креативності у професійній діяльності фахівця зумовлена багатофункціональністю соціальної роботи, різноманітним рольовим репертуаром працівників, що потребує варіативних підходів у вирішенні проблем клієнтів, особливо в сучасним умовах, коли «Україна як європейська держава ставить своїм завданням не лише забезпечення успішних соціальнополітичних та соціально-економічних реформ, але й досягнення нової якості життя, гармонізації суспільних відносин» [17, с. 6]. Креативний підхід у професійній діяльності у сфері соціальної роботи спроможний забезпечити гармонійний розвиток, розкриття особистісного, творчого потенціалу як фахівців, так і бути основою подальшої продуктивної взаємодії з усіма категоріями клієнтів, вирішення нових професійних завдань, що вимагають нестандартних творчих рішень. Особливо це $є$ актуальним для соціального працівника на всіх стадіях його професійного становлення. Окрім того, фахівець покликаний «сприяти встановленню гендерної рівності, отже, важливою частиною стратегії розвитку, мета якої полягає у тому, щоб як жінкам, так і чоловікам 
дати можливість виборсатися з тенет бідності та поліпшити свій життєвий рівень» [3, с. 17-18]. Тому нині залишається затребуваною інтелектуально розвинута особистість фахівця, яка вміє працювати і навчатися, гнучко й оперативно адаптуватись до сфери соціальної роботи, здатна застосовувати отримані знання, вміння й навички у практичній діяльності, шукати шляхи раціонального та нестандартного вирішення проблем осіб, які потребують сторонньої допомоги.

Аналіз останніх досліджень і публікацій. Дослідженню проблеми креативності, креативного потенціалу особистості присвячено праці Н. Вишнякова [1], Дж Гілфорда [2], Л. Лєскова [7], Ч. Лэндри [8], В. Моляко [5, 10], О. Попович [12], С. Шандрук [18] та інших науковців. Зокрема, О. Попович зазначає, що «існуючі психологічні концепції до аналізу креативного потенціалу особистості базуються на різних філософсько-методологічних засадах та зосереджені на інтерпретації феноменології творчої обдарованості, зокрема, на проявах дивергентного мислення, актуалізації інтелектуальної активності, на інтегрованих якостях творчої особистості» [12, с.39].

Проблеми гендеру, особливості формування гендерної чутливості у фахівців, включенням гендерного компоненту у практичні діяльність у сферу соціальної роботи досліджували О. Бойко [15], С. Гришак [4], В. Кравець [5], І. Мунтян [11] та ін.

Метою статті $є$ дослідження гендерно-вікових та організаційно-професійних чинників креативного потенціалу фахівців соціальної роботи.

Методика та організація дослідження.

У дослідженні взяли участь 625 фахівців з соціальної роботи з різних регіонів України на різних стадіях професійного становлення:

1) самовизначення в якості майбутнього фахівця - студенти віком до 23 років $(31,0 \%)$;

2) самопроектування (життєконструювання) майбутнього професійного шляху - молоді фахівці віком до 30 років $(15,0 \%)$;

3) саморегуляція у професійній діяльності - фахівці віком від 30 до 40 троків (16,3\%);

4) самоствердження та самовдосконалення у професійній діяльності - фахівці віком від 40 до 50 троків (11,2\%);

5) самореалізація фахівця як професіонала, досягнення «акме» - фахівці віком від 50 до 60 років $(14,7 \%)$;

6) рефлексія професійного досвіду і самотворення у після трудовому житті - фахівці віком від 60 років і більше $(11,7 \%)$.

3 них було виокремлено групи:

1) за статтю: жінки $(76,2 \%)$ і чоловіки $(23,8 \%)$;

2) за місцем проживання: місто $(75,7 \%)$ і село $(24,3 \%)$.

3) стажем роботи: не має $-26,2 \%$, до 1 року $-8,0 \%$, від 1 до 5 років $-10,9 \%$, від 5 до 10 років - 9,6\%, понад 10 років - 45,3\%.

Під час дослідження використовувались такі методи: аналіз, узагальнення і систематизація соціально-психологічної, педагогічної та науково-методичної літератури у галузі освіти та соціальної роботи, експертне анкетне опитування. Статистична обробка даних і графічна презентація результатів здійснювалася за допомогою пакета статистичних програм SPSS (версія 23.0).

Виклад основного матеріалу. Проблема оптимізації особистісно-професійного становлення фахівця спрямована на формування креативної особистості, здатної гнучко та успішно адаптуватися до сфери соціальної роботи, генерувати нові ідеї, творчо мислити. Креативний потенціал особистості фахівця 3 соціальної роботи $\epsilon$ цілісною динамічною особистісною властивістю, невичерпним ресурсом творчих психологічних здібностей, здатністю до інтелектуально-творчої ініціативної соціально-комунікативної активності та цілеспрямованої творчої діяльності, що передбачає самореалізацію, професійний саморозвиток та формування професійно-значущих якостей [9]. На думку О. Моляко, креативний потенціал поєднує дванадцять складових. Також автор стверджує, що «у найпростішому, найкоротшому варіанті можна говорити про творчий потенціал як про ресурс творчих можливостей людини, здатність конкретної людини до здійснення творчих дій, творчої діяльності в цілому» [5, с.14]. 3 огляду на специфіку соціальної роботи, варто погодитись 3 науковцем, що «творчість повинна стати нормою професійної діяльності та нормою підготовки до неї, тобто в кінцевому варіанті ми говоримо про те, що кожен фахівець має бути творчим фахівцем. Звичайно, рівні творчої діяльності завжди будуть різними, оскільки в кожному конкретному випадку творчі можливості у кожного конкретного працівника детерміновані його здібностями, обдарованістю, талантом» $[10$, с. $1-4]$. Так, в особистості фахівця з соціальної роботи креативність проявляється сприйнятливістю, чутливістю до проблем, відвертим ставленням до нових ідей і здатністю 
руйнувати стереотипи 3 метою створення нового, отримання незвичайних рішень життєвих проблем. Важливим є і те, що вона визначає творчу індивідуальність, яка, будучи вагомою характеристикою професійної творчості, становить інтегральну креативно-особову категорію, яка об'єднує: інтелектуально творчу ініціативу; інтелектуальні здібності; об'ємність та глибину знань; схильність до творчого сумніву; здатність вести внутрішню творчу боротьбу; відчуття новизни, жага пізнання; уміння бачити незвичайне в проблемі; професіоналізм [1, с. 13].

Цікавим у контексті досліджуваної проблеми є дослідження британських психологів W. Magadley та K. Birdi щодо впливу індивідуальних, групових та організаційних чинників на два ключових аспекти творчого процесу - породження ідей та їх впровадження. Результати їхнього емпіричного дослідження вказують, що чинники індивідуального рівня мають сильніший вплив на генерацію ідей, ніж на процес їхнього впровадження. В той же час, впровадження ідей більше пов'язано із груповими та організаційними чинниками [20].

Особливого значення набуває «інтелектуальний процес, результатом якого є нові відкриття чи створені людиною оригінальні продукти матеріальної й духовної культури» у нинішній час, період здійснення принципів гендерної рівності в процесі реалізації професійної діяльності. Окрім того, варто також звернути увагу, що у процесі вирішення проблем будьякого характеру фахівці з соціальної роботи стикаються 3 дискримінаційними практиками, оскільки важливу роль відіграє стать, яка підсилює прояви соціальної несправедливості. Тому нині є нагальною потреба у практичній реалізації соціальної роботи із врахуванням гендерної перспективи з різними категоріями населення: дітьми, молоддю, підлітками, людьми 3 інвалідністю, що зазнали насильства, особами похилого віку та іншими [13, с. 269; 4, с. 21-31].

Зважаючи на те, що однією з основних функцій соціальної роботи є створення рівних соціальних умов для розвитку особистості незалежно від статі важливим $\epsilon$ стирання диференціації між соціальними ролями чоловіка і жінки, нівелювання ієрархічності в у статевих стосунках, визнання цінності саме особистості (незалежно від статі).

3 метою визначення рівня креативного потенціалу, впливу гендерно-вікових та організаційно-професійних чинників на його формування на різних стадіях професійного становлення було проведено емпіричне дослідження серед фахівців 3 соціальної роботи. На першому етапі було визначено рівень креативного потенціалу особистості фахівців соціальної роботи за допомогою експертного анкетного опитування (табл. 1).

Таблиця 1. Розподіл досліджуваних фахівців із соціальної роботи за рівнями креативного потенціалу

\begin{tabular}{|c|c|}
\hline Рівні креативного потенціалу & Кількість досліджуваних у \% \\
\hline низький & 16,9 \\
\hline середній & 73,7 \\
\hline високий & 9,4 \\
\hline
\end{tabular}

Як випливає 3 табл. 1, для більшості фахівців з соціальної роботи характерний середній рівень креативного потенціалу $(73,7 \%)$, високий - у 9,4\% досліджуваних, а низький - у $16,9 \%$. Це свідчить про те, що більше половини фахівців володіють необхідними якостями (середній рівень), які дозволяють творити, шукати нові ідеї та рішення, але й мають певні проблеми, які ускладнюють творчий процес. Незначна частина фахівців має високий творчий потенціал, який дозволяє реалізувати особистісні та професійні можливості та здібності, набути різних форм творчості.. Окрім того, незначну частину фахівців характеризує обмежений творчий потенціал, що свідчить про нездатність адекватно оцінити себе, свої можливості, відсутність віри у себе, свої сили, що також не сприяє творчості, але за певних умов і особистісному бажанні фахівці здатні подолати цю проблему.

Крім того, встановлено статистично значущі відмінності щодо показника креативного потенціалу фахівців із соціальної роботи залежно від стадій професійного становлення (рис. 1). 


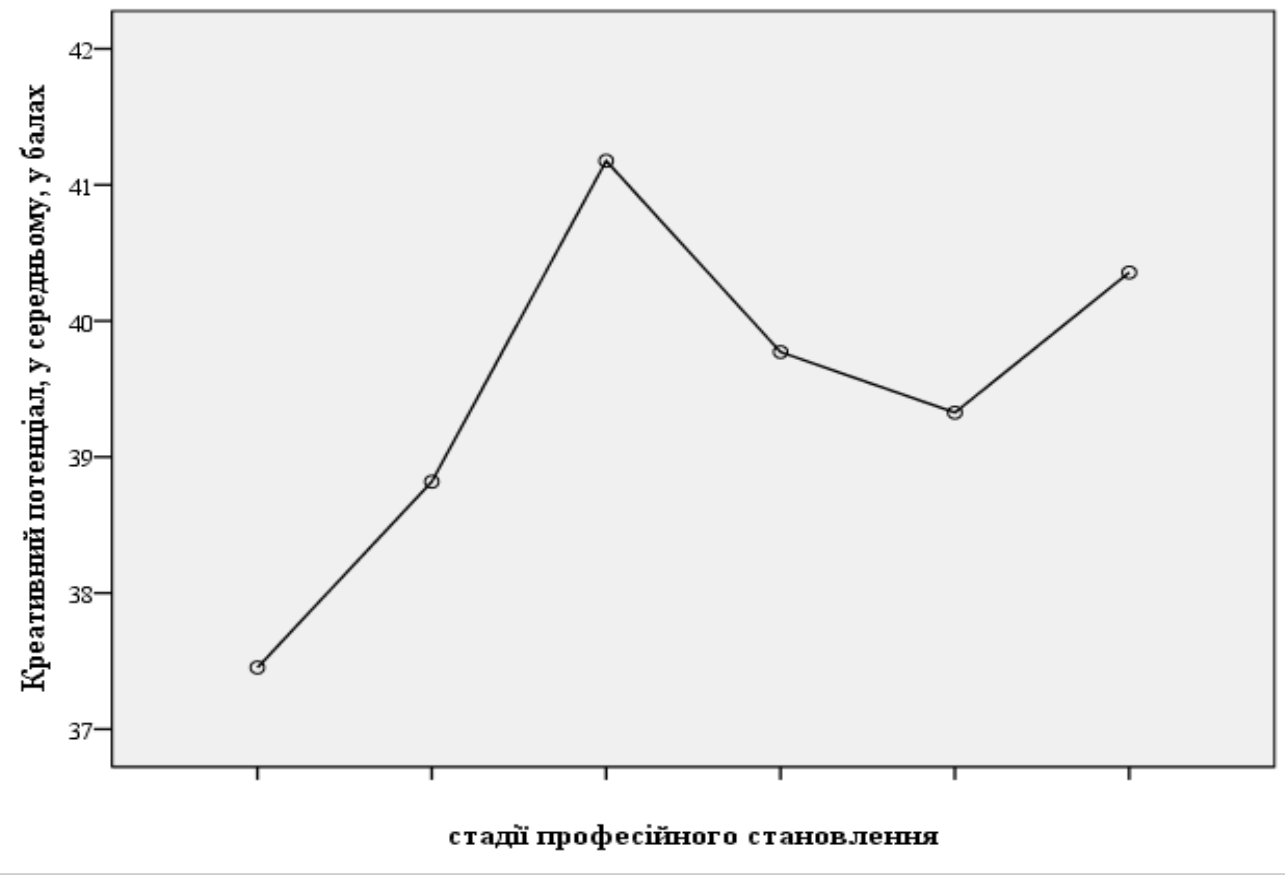

Рис. 1. Особливості креативного потенціалу фахівиів з соиіальної роботи залежно від стадій професійного становлення, де:

1 - стадія самовизначення в якості фахівия; 2 - стадія самопроектування (життєконструювання) професійного шляху; 3 - саморегуляція у професійній діяльності; 4 - саморозвиток, самоствердження та самовдосконалення у професійній діяльності; 5 - самореалізація фахівия як професіонала, досягнення «акме»; 6-рефлексія професійного досвіду і самотворення смислу подальшого життєвого шляху

Як видно з рис. 1, показник креативного потенціалу зазнає постійних змін на різних стадіях особистісно-професійного становлення. Зокрема, рівень його вираженості найбільш низький на стадії самовизначення в якості фахівця і складає у середньому 37,45 балів. На інших стадіях дещо зростає: на стадії самопроектування - у середньому 38,82 ; на стадії саморегуляції у професійній діяльності досягає найвищого розвитку і становить у середньому 41,18. Дещо знижується на стадіях саморозвитку, самоствердження та самовдосконалення і самореалізації і становить у середньому 39,78 та 39,33 відповідно. I знову зростає на стадії рефлексії професійного досвіду і самотворення смислу подальшого життєвого шляху - у середньому 40,36 балів $(\mathrm{p} \leq 0,01)$.

На нашу думку, це зумовлено особливостями особистісно-професійного становлення, оскільки креативність $\epsilon$ цілісним утворенням особистості фахівця, що забезпечує його здатність генерувати, розвивати, приймати і впроваджувати креативні ідеї у практичній діяльності у сфері соціальної роботи.

Спираючись на дослідження науковців Л. Лєскової [7, с. 76-78], I. Тодорової [15, с. 259-267], О. Чуль [16, с. 77-83], які зазначають, що креативний потенціал впливає на процес становлення особистості фахівця в цілому і формування індивідуальних особистісних якостей зокрема, на другому етапі емпіричного дослідження визначено гендерно-вікові особливості фахівців. Так, за результатами дисперсійного аналізу досліджено рівень креативного потенціалу фахівців 3 соціальної роботи залежно від статі і місця проживання. Зокрема, виявлено, що креативний потенціал фахівців жіночої статі (у середньому 39,43 бали) у незначній мірі перевищує показник творчості в осіб чоловічої статі (у середньому 38,27$)(\mathrm{p} \leq 0,05)$ (рис. 2).

Як видно з рисунку 1, показник креативного потенціалу у фахівців соціальної роботи дещо відрізняється за статтю і місцем проживання, зокрема у жінок у сільській місцевості він складає у середньому 39,19 , а в чоловіків дещо знижується $(37,73$ бали) $(\mathrm{p} \leq 0,01)$.

Це свідчить про те, що фахівцям варто розвивати, стимулювати у себе креативність як і будь-яку іншу якість, створюючи комфортні умови, позитивний соціально-психологічний клімат в колективі, надавати більше самостійності, свободи у досягненні цілей, прагнути до самореалізації себе як професіонала, розвитку неординарного мислення й поглядів, особливо у сільській місцевості. 


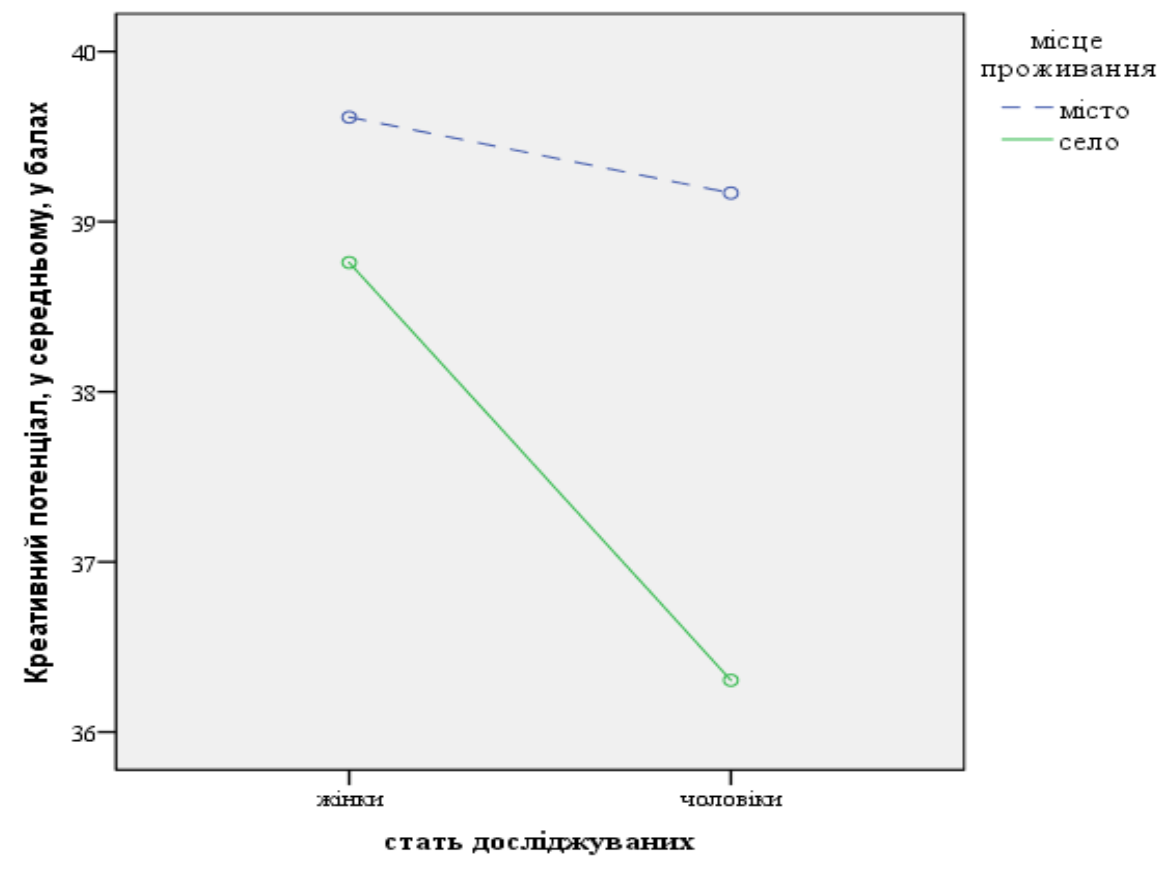

Рис. 2. Особливості креативного потенціалу фахівців з соиіальної роботи залежно від статі і місия проживання

Щодо зниження творчого потенціалу у чоловіків, то це може бути, на нашу думку, зумовлено ще й особливостями їхнього мислення, оскільки жінки $є$ більш гнучкими, здатні швидко змінювати способи дій, розвивати свої здібності, генерувати максимальну кількість ідей і засобів вирішення тієї чи іншої проблеми.

Третій етап нашого дослідження передбачав дослідження організаційно-професійних чинників креативного потенціалу фахівців 3 соціальної роботи. Так, дисперсійний аналіз дозволив виявити статистично значущі відмінності щодо креативного потенціалу фахівців із соціальної роботи залежно від стажу і місця проживання (рис. 3).

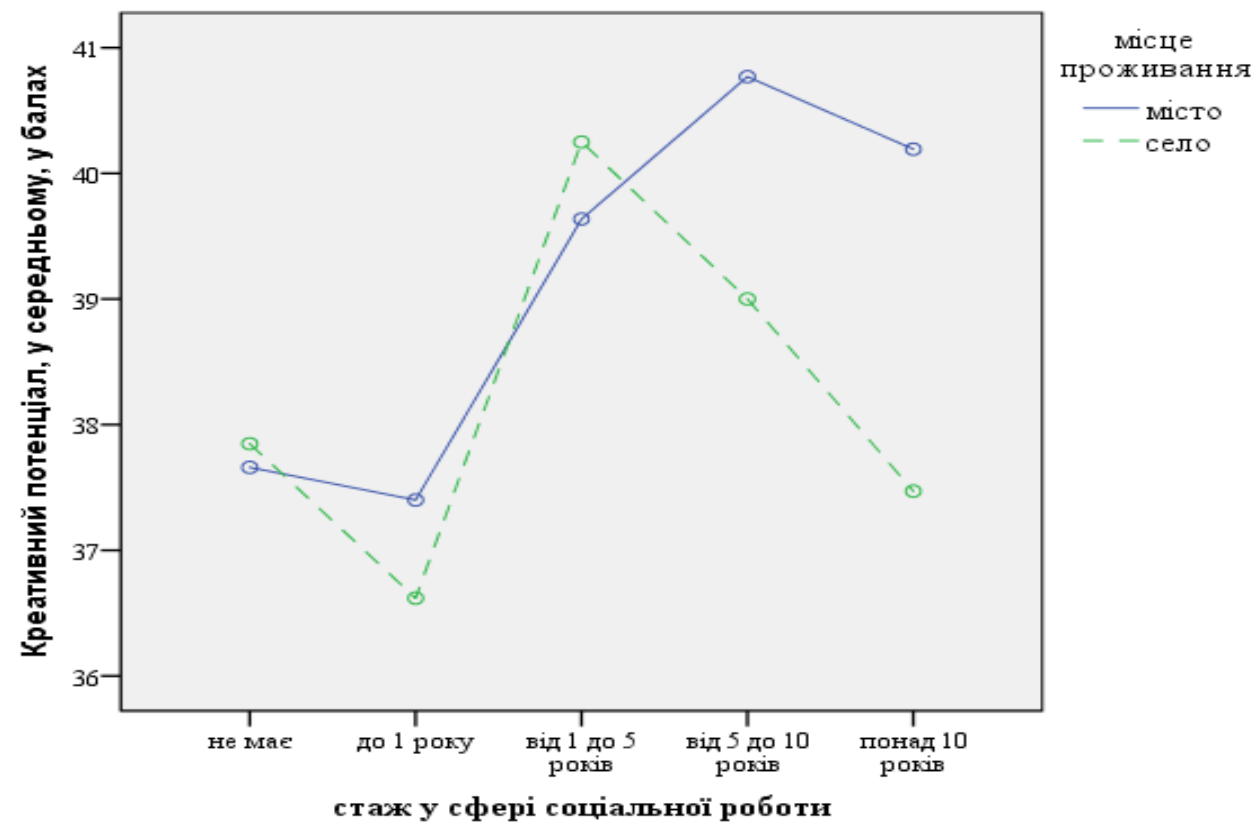

Рис. 3. Особливості креативного потенціалу фахівців з соиіальної роботи залежно від стажу і місия проживання 
Як випливає з рисунку 3, найменший показник креативного потенціалу характерний для фахівців (які працюють як в місті, так і в селі), що лише розпочинають трудову діяльність у сфері соціальної роботи і мають стаж до 1 року (у середньому 37,40 і 36,62 відповідно); максимального прояву він досягає з опануванням професійної діяльності і зростанням стажу - у місті цей період припадає на період набуття стажу від 5 до 10 років (у середньому 40,19 бали), а в селі - від 1 до 5 років (у середньому 40,25) (p $\leq 0,01)$. Дещо знижується показник креативного потенціалу у процесі трудової діяльності, коли фахівець набуває стажу роботи понад 10 років у місті (у середньому 40,19) і набуває різкого зниження у працівників у службах сільської місцевості з набуттям стажу від 5 до 10 років і понад 10 років, відповідно показник креативного потенціалу становитиме у середньому 39,00 i 37,47 бали $(\mathrm{p} \leq 0,01)$. Це, на нашу думку, зумовлено особливостями соціальної і професійної адаптації до практичної діяльності та особливостями професійного зростання і становлення в цілому у сфері соціальної роботи. Щодо працівників у сільській місцевості, то зниження креативного потенціалу, на нашу думку, зумовлено як внутрішніми психологічними факторами самообмеженнями, установками, недостатньою цілеспрямованістю, так і гендерними стереотипами діяльності й умовами, в яких вони знаходяться, реалізацією принципу рівних прав і можливостей для обох статей, прагненням до самореалізації у професійній діяльності.

Висновки. Встановлено гендерно-вікові та організаційно-професійні особливості креативного потенціалу фахівців соціальної роботи на різних стадіях професійного становлення, виявлено недостатній рівень креативного потенціалу загалом, досліджено рівень креативного потенціалу фахівців з соціальної роботи залежно від статі, місця проживання, стажу роботи. Показано, що креативність $є$ : потенційною здібністю особистості фахівця, яку можна розвивати і стимулювати; ключовим фактором досягнення успіху у професійній діяльності у сфері соціальної роботи. Розвиток креативного потенціалу у фахівців сприяє реалізації однієї з основних функцій соціальної роботи - створенню умов для реалізації кожної людини та усунення бар'єрів між соціальними ролями чоловіка і жінки, визнання цінності кожної особистості.

Встановлено статистично значущі відмінності щодо показника креативного потенціалу фахівців із соціальної роботи залежно від стадій професійного становлення, зокрема показник креативного потенціалу найбільш низький на стадії самовизначення в якості фахівця.

\section{ЛIТЕРАТУРА}

1. Вишнякова Н. Ф. Психологические основы развития креативности в профессиональной акмеологии: автореф. дис. ... д-ра психол. наук. - М., 1996. 24.

2. Гилфорд Дж. Три стороны интеллекта, Психология мышления. Под ред А. М. Матюшкина. - М., 1965. 433-456.

3. Гендерні складові процесу розвитку. Витяг зі звіту Світового Банку. Гендер і державна політика, пер. $з$ англ.; упоряд. П. Ренкін. - К, 2004. 17-60.

4. Гришак С. М. Особливості формування сучасних егалітарних поглядів у майбутніх спеціалістів соціальної сфери в процесі підготовки до реалізації ідеї гендерної рівності у професійній діяльності. Вища школа. Херсонський державний університет. Режим доступу: http://ekhsuir.kspu.edu/handle/123456789/4754. 21-31.

5. Здібності, творчість, обдарованість: теорія, методика, результати досліджень. За ред. В. О. Моляко, О. Л. Музики. Житомир, 2006. 320.

6. Кравець В. П. Гендерна педагогіка. Тернопіль, 2003. 416.

7. Лєскова Л. Ф. Феномен креативності в професійній діяльності менеджера соціальної роботи. Актуальні проблеми філософії та соціології. 2016. 76-78.

8. Лэндри Ч. Креативный город. М., 2011. 399.

9. Маркова А. К. Психология профессионализма. М., 1996. 312.

10. Моляко В. О. Психологія творчості - нова парадигма дослідження конструктивної діяльності людини. Практична психологія та соціальна робота. К., 2004. №8. 1-4.

11. Мунтян I. С. Гендерний підхід у професійній підготовці студентів вищих педагогічних закладів: дис. ...канд.. пед. наук: 13.00.04. Одеса, 2004. 19.

12. Попович О. В. Філософські виміри креативного потенціалу особистості. Вісник Житомирського державного університету імені Івана Франка. 2013. Вип. 6. 36-41 Режим доступу: http://nbuv.gov.ua/UJRN/VZhDU_2013_6_8

13. Психологічна енциклопедія. Автор-упорядник О. М. Степанов. К., 2006. 424.

14. Психологічні дослідження творчого потенціалу особистості: монографія. Авт. кол., наук. керівник В. О. Моляко. К., 2008. 208. 
15. Тодорова I. С. Розвиток креативно-інноваційного потенціалу майбутніх менеджерів. Психологія i особистість. 2017. № 1(11). 259-267.

16. Чуль О. М. Креативний потенціал як конвергентний чинник регіонального розвитку. Економічний форум. 2017. № 1. 77-83 Режим доступу: http://nbuv.gov.ua/UJRN/ecfor_2017_1_13

17. Формування у молоді гендерно-відповідальної поведінки (на прикладі українських ВНЗ). За заг. ред. Н. Світайло. Суми, 2013. 209.

18. Шандрук С.К. Психологічні засади розвитку професійних творчих здібностей майбутніх практичних психологі : 19.00.07 : дис. ... д-ра психол. наук; Тернопільський нац. ун-т. Тернопіль, 2016. 458.

19. Amabile T. M. How to Kill Creativity. Harvard Business Review. 76 . № 5 (September-October 1998). 7687. Retrieved from: https://hbr.org/1998/09/how-to-kill-creativity

20. Magadley W., Kamal Birdi. Two sides of the innovation coin? An emprical investigation of the relative correlates of idea generation and idea implementation. International Journal of Innovation Management. February 2012. Vol. 16. № 01. 